embarking on so comprehensive and ambitious a book. I do not doubt that its sequel, a companion book on the animals of the Antarctic and Subantarctic, announced on the dust-jacket, will be an entirely different proposition, for it is in the south that the author's most notable polar experience has been gained. Very little of the present book except the lively prose owes its origin to Stonehouse. Even selecting agency pictures of places and things one has never seen and giving them captions is asking for trouble; compiling a popular scientific text in similar circumstances is perilous indeed. The book consequently has little depth and is sometimes factually adrift. If like the Humane Mikado one could make the punishment fit the crime, the author would be sent to arctic Siberia (alternatively the District of Franklin) for a summer or two, with hard ecological labour.

V.C. WYNNE EDWARDS

\title{
The Struggle for the Great Barrier Reef, by Patricia Clare. Collins, f2.50.
}

Refreshingly different from the recent deluge of books about various aspects of the Reef, this is neither a picture book nor an account of reef life, but an account of the Reef's future. Until recently no one has questioned this and little scientific attention has been given to this enormous and extremely complex ecosystem with incredible species diversity.

Miss Clare has woven a fascinating story, and her skilful descriptions of the people most intimately involved make whole sections read like a novel. Other chapters describe her visits to the Reef and the threats from mining and oil interests, increasing coastal development, oil tankers, uncontrolled tourism etc. She gives a wide insight into the problems currently to be faced on this assemblage of reefs extending 1250 miles along Australia's eastern seaboard, and leaves the reader with a feeling of considerable disquiet as to its future and the way in which decisions are arrived at.

Of the fifteen colour photographs, many of them extremely good, ten are by Keith Gillett, the doyen of Reef photographers. Since a whole chapter early in the book is devoted to the crown-of-thornsstarfish threat to the Reef it is unfortunate that plate 1, captioned 'Crown-of-thorns starfish' shows a common reef sea urchin. All the captions are terse and most uninformative. For instance the caption for plate 4 - a superbly reproduced photograph of the fringing vegetation at Heron Island - is merely, 'Trees and beach - Heron Island'. Apart from the fact that this much is obvious, identification of the trees as casuarinas would at least be informative. But these comments do not detract from the text; I hope that it will be widely read, both inside and outside Australia.

ROBERT BUSTARD

The House of Life - Rachel Carson at Work, by Paul Brooks. Houghton Mifflin, \$8.95.

Rachel Carson was a bestselling author, with books translated into a score of languages, long before she published Silent Spring, her last and best known work. An aquatic biologist, she wrote mostly about the sea and the shore and their teeming life, skillfully mingling scientific knowledge with her sense of wonder at the endless beauties of nature; and she wrote well. 